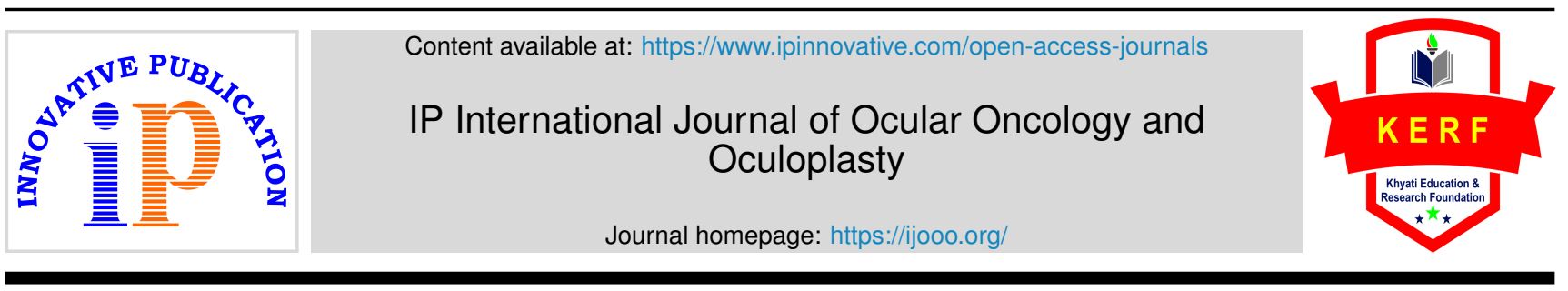

Original Research Article

\title{
A clinical study of vitamin d supplementation in diabetic retinopathy patients with type 2 diabetes mellitus
}

\author{
Rani Sujatha M.A ${ }^{1}$, Ranjitha $\mathrm{KC}^{\odot}{ }^{1, *}$ \\ ${ }^{1}$ Dept. of Ophthalmology, Dr. B. R. Ambedkar Medical College and Hospital, Bengaluru, Karnataka, India
}

\section{A R T I C L E I N F O}

\section{Article history:}

Received 11-03-2021

Accepted 13-03-2021

Available online 28-04-2021

\section{Keywords:}

Diabetic retinopathy

vitamin D

Diabetic millitus

\begin{abstract}
A B S T R A C T
Aim: To evaluate the effect of supplementation of Vitamin D in delaying the progression of diabetic retinopathy (DR), and its use as a predictor for the severity of Diabetic Retinopathy.

Materials and Methods: 100 patients with type 2 diabetes melitus and diabetic retinopathy were included in this retrospective study which was carried out at the vitreoretinal services, department of ophthalmology at DR B.R Ambedkar medical college and hospital over a period of 1 year.

Results: Out of 100 patients, 59 were males and 41 were females. At 3 months, no progression noted in moderate, severe and very severe NPDR. However in control group 20\% progressed to high risk PDR which is not found in cases. It was statistically significant ( $\mathrm{p}$ value $<0.05$ ). At 6 months progression to high risk PDR noted only in $2 \%$ of the cases but in $28 \%$ controls and even to progression to early PDR was increased to $12 \%$ in controls. It was statistically significant ( $\mathrm{p}$ value $<0.05$ ).

Conclusions: From the results of the study we can conclude that oral supplementation of Vitamin D in addition to the recommended treatment with photocoagulation, delays the progression of severe, very severe and early PDR. Our study demonstrated that low levels of vitamin D may be a risk marker of development or progression of diabetic retinopathy.

(C) This is an open access article distributed under the terms of the Creative Commons Attribution License (https://creativecommons.org/licenses/by/4.0/) which permits unrestricted use, distribution, and reproduction in any medium, provided the original author and source are credited.
\end{abstract}

\section{Introduction}

Diabetes Mellitus continues to be a major health burden all over the world. According to the latest data by the WHO, almost 422 million individuals are estimated to be suffering from diabetes mellitus. ${ }^{1,2}$ The increasing trend towards unhealthy food practices, sedentary lifestyle and physical inactivity can be attributed to this rise in the burden of diabetes mellitus. diabetic retinopathy remains a leading cause of blindness all over the world especially in the working age group with maximum patients presenting in the late stages with significant visual loss due to lack of awareness. Vitamin D deficiency has been implied as a risk factor for development of diabetes mellitus by several studies. ${ }^{3,4}$ Serum vitamin D levels have a role in preventing angiogenesis and reducing pro-inflammatory

\footnotetext{
* Corresponding author.

E-mail address: ranjitha.jeetu@ gmail.com (Ranjitha KC).
}

cytokines thereby implicating a protective role against development of diabetic retinopathy. 5,6

\section{Materials and Methods}

100 patients with type 2 diabetes melitus and diabetic retinopathy were included in this retrospective study which was carried out at the vitreoretinal services, departmentof ophthalmology at DR B R Ambedkar medical college and hospital over a period of 1 year

\subsection{Inclusion criteria}

1. Patients aged 40 years and above.

2. Patients with type 2 Diabetes Mellitus who are diagnosed as non proliferative diabetic retinopathy or Proliferative Diabetic Retinopathy. 


\subsection{Exclusion criteria}

1. Patients with type 1 Diabetes mellitus

2. Patients previously on vitamin $D$ supplementation.

3. Patients with vitreous haemorrhage.

4. Patients with diabetic retinopathy associated with CNVM

5. History of disorders affecting the metabolism of Vitamin D and illness including renal failure, hepatic dysfunction, and musculoskeletal disorders were excluded.

All patients were screened with a detailed history including nature \& duration of symptoms, duration of exposure to sunlight, and diet history.

1. Ocular examination

2. Visual acuity was assessed by Snellen's chart and refractive status was noted

3. Anterior segment evaluation with slit lamp biomicroscopy was performed

4. Intraocular pressure was measured using Goldmann Applanation tonometer

5. Diabetic retinopathy was evaluated by a dilated fundus examination using 90D \& indirect ophthalmoscopy

6. Spectral domain optical coherence tomography

7. The Diabetic retinopathy was classified as per the ETDRS.

8. 50 patients received weekly oral supplementation of 4000 IU of Vitamin D for a duration of 6 months, constituting the treatment arm, while the other 50 patients served as the control arm.

\section{Results}

A total of 100 patients were reviewed. Out of these 59 were males and 41 were females [Figure 1] in the age range of 41-75 years [Figure 2]. $22.62 \%$ cases and $24 \%$ controls had visual acuity of 3/60-6/60. $40 \%$ cases and $36 \%$ controls had $6 / 36-6 / 24$. 24\% cases and 24\% controls had 6/18-6/12 and $14 \%$ cases and $16 \%$ controls had 6/9-6/6 [Figure 3]. Among the 100 patients enrolled in the study a total

76 patients were vitamin $\mathrm{D}$ deficient $(<20 \mathrm{ng} / \mathrm{ml}), 15$ patients were found to be vitamin D insufficiency (20$30 \mathrm{ng} / \mathrm{ml}$ ), 9 patients were found to have normal vitamin $\mathrm{D}$ levels .The mean vitamin $\mathrm{D}$ levels at presentation was 23.48ng/ml [Table 1].

Mean vitamin D at 6 months among cases was found to be $39.8 \mathrm{ng} / \mathrm{ml}$. Mean vitamin D at 6 months among controls was $17.2 \mathrm{ng} / \mathrm{ml}$ [Table 2].

Of the 100 patients 10 patients $(20 \%)$ had moderate NPDR in cases and 13(26\%) in controls and 19(38\%) in cases with severe NPDR and 21(48\%) in controls. 18(36\%) in cases and 14(28\%) in controls in very severe NPDR and $3(6 \%)$ cases in early PDR and 2(4\%) in controls [Table 3]. At 3 months, no progression noted in moderate, severe and very severe NPDR. However in control group 20\% progressed to high risk PDR which is not found in cases. It was statistically significant ( $p$ value $<0.05$ ) [Table 4]. At 6 months progression to high risk PDR noted only in $2 \%$ of the cases but in $28 \%$ controls and even to progression to early PDR was increased to $12 \%$ in controls. It was statistically significant $(\mathrm{p}$ value $<0.05$ ) [Table 5].
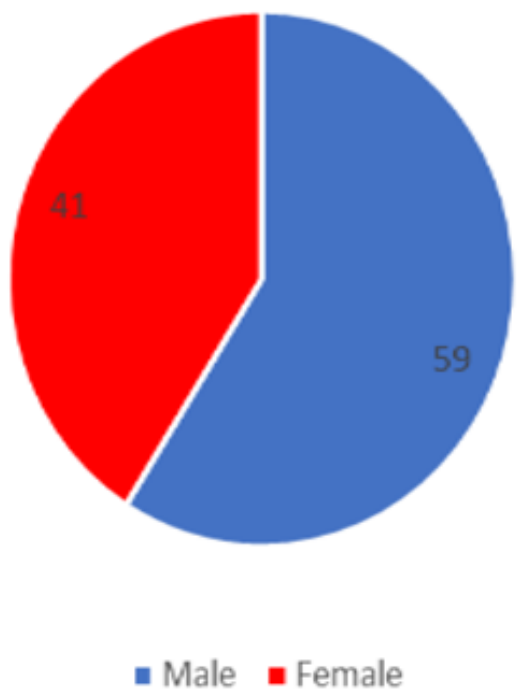

Fig. 1: Ratio of males to females

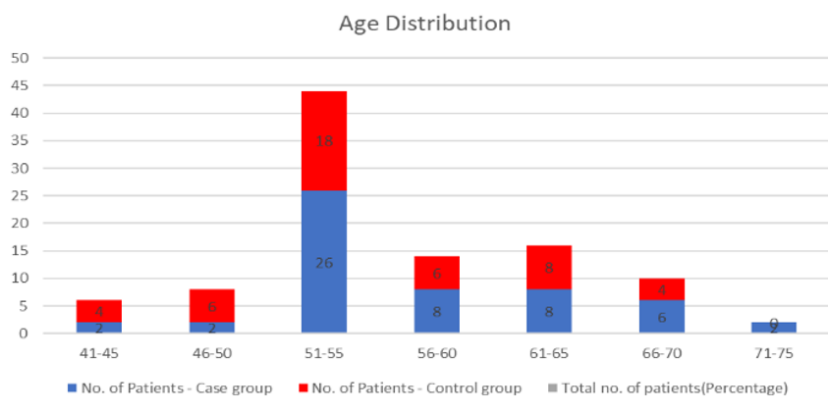

Fig. 2: Age distribution

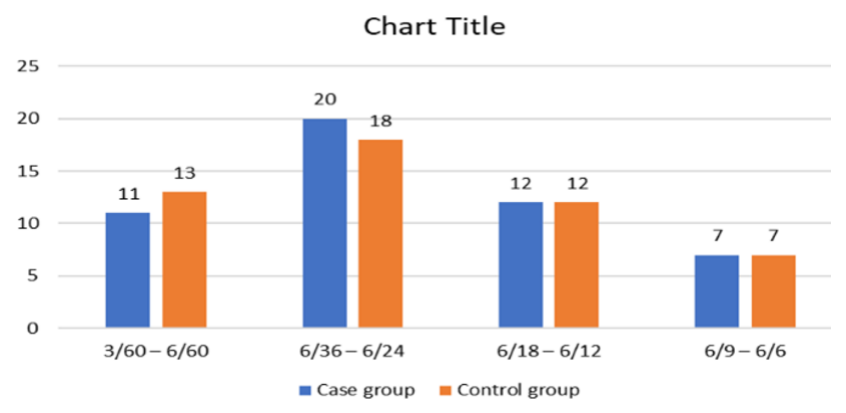

Fig. 3: Visual acuity distribution 
Table 1: Distribution of baseline vit D levels

Serum 25 hydroxy vitamin D levels
$(\mathbf{n g} / \mathbf{m l})$
$<20$
$20-30$
$30-100$
$>100$

\section{No. of patients}

$\begin{array}{cc}\text { Moderate NPDR } & \text { Severe NPDR } \\ 14 & 31 \\ 5 & 6 \\ 4 & 3 \\ 0 & 0\end{array}$

Very severe NPDR
28
3
1
0

$\begin{array}{cc}\text { Early PDR } & \text { Total patients } \\ 3 & 76 \\ 1 & 15 \\ 1 & 9 \\ 0 & 0\end{array}$

Table 2: Distribution of vit D levels at 6months in cases

\begin{tabular}{lcc}
\hline Serum 25 hydroxy vitamin D3 level ( $\mathbf{n g} / \mathbf{m l})$ in cases at 6 months & No. of patients & Percentage \\
$<20$ & 2 & $4 \%$ \\
$20-30$ & 40 & $80 \%$ \\
$30-100$ & 8 & $16 \%$ \\
$>100$ & 0 & $0 \%$ \\
\hline
\end{tabular}

Table 3: Severity of retinopathy

\begin{tabular}{lcccc}
\hline $\begin{array}{l}\text { Severity of retinopathy at } \\
\text { presentation }\end{array}$ & Case group & Percentage in case group & Control group & $\begin{array}{c}\text { Percentage in control } \\
\text { group }\end{array}$ \\
Moderate NPDR & 10 & $20 \%$ & 13 & $26 \%$ \\
Severe NPDR & 19 & $38 \%$ & 21 & $42 \%$ \\
Very severe NPDR & 18 & $36 \%$ & 14 & $28 \%$ \\
Early PDR & 3 & $6 \%$ & 2 & $4 \%$ \\
High-risk PDR & 0 & $0 \%$ & 0 & $0 \%$ \\
\hline
\end{tabular}

Table 4: Severity of retinopathy at 3 months

\begin{tabular}{lcccc}
\hline $\begin{array}{l}\text { Severity of } \\
\text { retinopathy at 3 } \\
\text { month }\end{array}$ & $\begin{array}{c}\text { No. of eyes in case } \\
\text { group }\end{array}$ & $\begin{array}{c}\text { Percentage in case } \\
\text { group }\end{array}$ & $\begin{array}{c}\text { No. of eyes in control } \\
\text { group }\end{array}$ & $\begin{array}{c}\text { Percentage in control } \\
\text { group }\end{array}$ \\
Moderate NPDR & 3 & $18 \%$ & 10 & $20 \%$ \\
Severe NPDR & 20 & $40 \%$ & 18 & $36 \%$ \\
Very severe NPDR & 17 & $34 \%$ & 11 & $22 \%$ \\
Early PDR & 4 & $8 \%$ & 1 & $2 \%$ \\
High-risk PDR & 0 & $0 \%$ & 10 & $20 \%$ \\
\hline
\end{tabular}

Table 5: Severity of retinopathy at 6 months

\begin{tabular}{lcccc}
\hline $\begin{array}{l}\text { Severity of retinopathy } \\
\text { at } 6 \text { month }\end{array}$ & $\begin{array}{c}\text { No. of eyes in } \\
\text { case group }\end{array}$ & $\begin{array}{c}\text { Percentage in case } \\
\text { group }\end{array}$ & $\begin{array}{c}\text { No. of eyes in } \\
\text { control group }\end{array}$ & $\begin{array}{c}\text { Percentage in control } \\
\text { group }\end{array}$ \\
Moderate NPDR & 6 & $12 \%$ & 7 & $14 \%$ \\
Severe NPDR & 18 & $36 \%$ & 11 & $22 \%$ \\
Very severe NPDR & 20 & $40 \%$ & 12 & $24 \%$ \\
Early PDR & 5 & $10 \%$ & 6 & $12 \%$ \\
High-risk PDR & 1 & $2 \%$ & 14 & $28 \%$ \\
\hline
\end{tabular}

\section{Discussion}

Diabetic retinopathy remains one of the leading causes of visual loss and after duration of diabetes exceeding 15 years, it affects three out of four diabetic patients. Commonest cause of significant loss of vision in DR is diabetic macular edema. ${ }^{7}$ In our study $75 \%$ of patients belonged to the 5 th and 6 th decades of life. This may be due to the fact that prevalence of systemic diseases such as diabetes, increases with increasing age according to Daniel M.Tayloret al. Survey ophthalmology. ${ }^{8}$ In the study, $59 \%$ males and $41 \%$ females were affected with diabetic retinopathy. Although an increased percentage of males were found to be affected, no significant male preponderance was observed. This finding was consistent with previous studies. Among the 100 patients enrolled in the study a total of 76 patients had vitamin $\mathrm{D}$ deficient and 15 patients were found to be vitamin D insufficient and 9 patients were found to have normal vitamin D levels.

Aksoy H. et. Al demonstrated that decrease in vitamin $\mathrm{D}$ resulted in uncontrolled angiogenesis and 
neovascularization of retina. ${ }^{9}$ A cross-sectional study of type 2 diabetic patients conducted by Suzuki A et. Al. showed a significant association between the existence of proliferative retinopathy and a decrease in $25(\mathrm{OH})$ D. ${ }^{10} \mathrm{~A}$ study conducted by Joergensen $\mathrm{C}$ et al found a decrease in $25(\mathrm{OH}) \mathrm{D}$ according to the number of microvascular complications present. ${ }^{11}$ A clinic-based, cross-sectional study by Payneset et al. to assess the relationship between vitamin D status and diabetic retinopathy concluded that diabetic subjects, especially those with PDR, have lowered $25(\mathrm{OH}) \mathrm{D}$ levels than those without diabetes. ${ }^{12}$

In our study the mean serum 25 hydroxy Vitamin D level of $39.8 \mathrm{ng} / \mathrm{ml}$ was attained in the cases following 6 months of oral supplementation, suggesting that this dose used was adequate for normalization of serum vitamin $\mathrm{D}$ levels. The mean levels remained deficient $(17.2 \mathrm{ng} / \mathrm{ml})$ in the controls at the end of 6 month. At 3 months, no progression noted in moderate, severe and very severe NPDR. However in control group $20 \%$ progressed to high risk PDR which is not found in cases. It was statistically significant ( $p$ value $<0.05$ ). At 6 months progression to high risk PDR noted only in $2 \%$ of the cases but in $28 \%$ controls and even progression to early PDR was increased to $12 \%$ in controls. It was statistically significant ( $\mathrm{p}$ value $<0.05$ ).

\section{Conclusion}

From the results of this study we can conclude that oral supplementation of Vitamin D in addition to the recommended treatment with photocoagulation, delays the progression of severe, very severe and early PDR. Our study demonstrated that low levels of vitamin D may be a risk marker of development or progression of diabetic retinopathy. It is advisable to conduct ophthalmologic examination at regular intervals in diabetics whose serum 25 hydroxy vitamin D concentrations are diminished. Serum 25 hydroxy vitamin D concentrations could become a useful biochemical marker to predict the severity of DR in patients with diabetes mellitus in the future.

\section{Conflicts of Interest}

All contributing authors declare no conflicts of interest.

\section{Source of Funding}

None.

\section{References}

1. World Health Organization,Global Report on Diabetes. Geneva; 2016.

2. Maurya RP. Diabetic retinopathy: My brief synopsis. Ind J Clin Exp Ophth. 2015;1(4):189-90.

3. Baz-Hecht M, Goldfine AB. The impact of vitamin D deficiency on diabetes and cardiovascular risk. Curr Opin Endocrin Diab Obes.

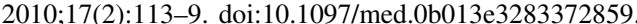

4. Judd SE, Tangpricha V. Vitamin D Deficiency and Risk for Cardiovascular Disease. Am J Med Sci. 2009;338(1):40-4. dor:10.1097/maj.0b013e3181aaee9].

5. Palomer X, González-Clemente JM, Blanco-Vaca F, Mauricio D. Role of vitamin D in the pathogenesis of type 2 diabetes mellitus. Diabetes Obes Metab. 2008;10(3):185-97. doi:10.111/].1463प326.20070070X.

6. Albert DM, Scheef EA, Wang S. Calcitriol is a potent inhibitor of retinal neovascularization. Invest Ophthalmol Vis Sci. 2007;48:232734.

7. Maurya RP. Dabetic macular edema: An overview. Indian J Clin Exp Ophthalmol. 2019;5(1):1-2. 10:-10/823/2305-145120190026

8. Taylor DM. Aphakic cystoid macular edema. Longterm clinical observations. Survey Ophthalmol. 1984;28(2):437-41.

9. Aksoy H, Akçay F, Kurtul N, Baykal O, Avci B. Serum 1,25 dihydroxy vitamin $\mathrm{D}(1,25(\mathrm{OH}) 2 \mathrm{D} 3), 25$ hydroxy vitamin $\mathrm{D}$ $(25(\mathrm{OH}) \mathrm{D})$ and parathormone levels in diabetic retinopathy. Clin Biochem. 2000;33(1):47-51. 001:10.1016/s0009-9120(99)00085-5.

10. Suzuki A, Kotake M, Ono Y, Kato T, Oda N, Hayakawa N, et al. Hypovitaminosis D in Type 2 Diabetes Mellitus: Association with Microvascular Complications and Type of Treatment. Endocr J. 2006;53(4):503-10. do1:10.1507/endocr].k06-001.

11. Joergensen $\mathrm{C}$, Hovind $\mathrm{P}$, Schmedes A, Parving HH, Rossing $\mathrm{P}$ Vitamin D Levels, Microvascular Complications, and Mortality in Type 1 Diabetes. Diabetes Care. 2011;34(5):1081-5. 10:0102337dcl0-2459.

12. Payne F, Ray R, Watson DG. VitaminD insufficiency in diabetic retinopathy. Endocr Pract. 2012;18:185-93.

\section{Author biography}

Rani Sujatha M.A, HOD

Ranjitha KC, Post Graduate Student (1) https://orcid.org/0000-00018393-4607

Cite this article: Sujatha M.A R, Ranjitha KC. A clinical study of vitamin d supplementation in diabetic retinopathy patients with type 2 diabetes mellitus. IP Int J Ocul Oncol Oculoplasty 2021;7(1):64-67. 